\title{
The Implementation of Brain-Based Learning on Speaking Skill based on Eric Jensen's Perspective
}

\author{
Al Lastu Nurul Fatim ${ }^{1}$, Dwi Rahmadanty Anjelia ${ }^{2}$, Abdul Basid $^{3}$ \\ \{1allastufatim@gmail.com, ${ }^{2}$ dwirahmadanty@gmail.com, ${ }^{3}$ abdulbasid@bsa.uin-malang.ac.id\} \\ ${ }^{1,2,3}$ Universitas Islam Negeri Maulana Malik Ibrahim, Jalan Gajayana No. 50, Malang, Indonesia
}

\begin{abstract}
This study is inspired by the learning of speaking skills in Mts Nurul Huda Malang predominantly used in the left brain. But in reality, the right brain has a function of creativity and motivation. The goals of the study are: (1) to describe the implementation of brain-based learning on speaking skill based on Eric Jensen's perspective; (2) to understand the factors causing the effectiveness of brain-based learning on speaking skill based on Eric Jensen's perspective; (3) to know the effectiveness of the implementation of brain-based learning on speaking skill based on Eric Jensen's perspective. This study is a qualitative and quantitative approach. The data collection techniques used are observation, interview, and test. The data qualitative is analyzed by using Miles and Huberman's model and the quantitative data is analyzed by using SPSS application. The results of this study are: (1) the implementation of brain-based learning applied the 7 stages by functioning 2 hemispheres of the brain and balancing 3 brain waves; (2) several factors influence the effectiveness of the implementation brain-based learning. They are coloring in the learning process, deployment of concrete images, listening to music during the learning process, giving time for a drinking water and seating arrangements; (3) the effective implementation of brain-based learning is worth testing in field with t-test result in experiment class that is t-count $>\mathrm{t}$-table $(5.657>2.306)$.
\end{abstract}

Keywords: The Implementation, Brain-Based Learning, Speaking Skill.

\section{Introduction}

Speaking is to have a conversation with someone; a language to be able to use a particular language [1]. Speaking activities that occur in everyday life becomes a skill in language proficiency. In learning a second language, especially the language at least speaking skills have been based on the skills of listening, then the vocabulary mastery ability and the bravery to reveal what is in everyone's mind [2].

Speaking skills became the principal skills in learning a foreign language, a skill that has made the most powerful purpose in its language learning. Therefore, it is expected as teachers and students can talk to provide information and skills that have been studied previously. Speaking skills has also become a means of listening skills before, most people skipped half the time for listening and few of them skipped speaks [3]. Second language learning in speaking skills applies to train the ability of students in conveying the message to others. 
The implementation of speaking skills during the learning process in the second language is represented by the left brain, while the right brain whereas it serves as a supporting and retaining language skills. But in fact, learning speaking skills in Indonesian especially in MTs Nurul Huda Malang dominant used of left-brain, when learning takes place teachers present materials or tasks by the design of learning that has been prepared. However teachers are aware that students are not able to save new information into the memory of the unconscious, so they tend to forget the new information that has been given by the teachers before.

Phenomena that occur in the field that teachers have yet to figure out how the brain works according to the function of hemispheres. Then the researchers like to implement new learning which is can balance both hemisphere's function, namely brain-based learning in Eric Jensen's perspective. Brain-based learning is learning that is aligned with how the brain naturally designed for learning [4]. This study considers how the brain learns with optimum, then the students learn according to function or not exceed the limits of their brain abilities, so that students do not saturate, bored or feel unfettered in the process learning. In the process of implementation brain-based learning, teachers can apply the 7 stages in Eric Jensen's perspective, namely: 1) pre-exposure; 2) preparation; 3) initiation and acquisition; 4) elaboration; 5) incubation and coding memory; 6) verification and checking of belief; 7) celebrate and integration.

Brain-based learning on Eric Jensen's perspective by applying the seven stages, maybe the solution to the problems that occur in the field. Because, this study can help teachers to develop a language environment that can provide motivation and emotions of the students in developing the brain that it has, when the brain students it needed a break and when the brain students need motivation during the learning process. Then every teacher must change the way of their learning methods and think in the cognitive, emotional, and motivational views that are by following students' brain functions.

Previous exposure is supported by several studies that discuss the brain-based learning with different focus, as the first researcher focused his study on how the stress can be reduced with the help of effective learning mechanism [5]. The second researcher focused his study on the effect of Brain-Based Learning (BBL) with a contextual approach to mathematics achievement [6]. The third researcher focused his study on the brain's natural learning system of model BBL and WBT [7]. The fourth researchers focused his study on the effect of teaching the units of "Belief in Allah" and "Worship in Islam" [8]. The fifth researcher focused his study on the development strategies of learning speaking skills students [9].

From the results of several studies on the above similarity research that will be examined by researchers that are equally used brain-based learning, as for a difference from some above research more focused on general learning material, While the researchers focused on learning the Arabic language.

Based on the above exposure, the researchers focused their study to describe, to understand the factors causing the effectiveness, and to know the effectiveness of the implementation of brain-based learning on speaking skills based on Eric Jensen's perspective in MTs Nurul Huda. This discussion shows how to implement brain-based learning according to Eric Jensen's perspective and several factors supporting effectiveness by following the field so that the brain-based learning can be implemented, and achieved by researchers well. 


\section{Research Method}

The population in this study is students of class VIII MTs Nurul Huda Malang. This study also used a qualitative and quantitative approach. Data collection used in this study are observation, interviews, and tests. The primary data source in this study is data obtained from test results, while secondary data sources obtained are data from interviews, observations, books, research journals concerned with Arabic learning, brain-based learning, and documents related to this study. The technique of qualitative data analysis used Miles and Huberman's model, which has several stages such as data collection, data reduction, data display, and conclusions [10]. While technique quantitative data analysis used SPSS with the t-test model.

\section{Results And Discussion}

\subsection{The Implementation of Brain-Based Learning}

Brain-based learning on speaking skills based on Eric Jensen's perspective to help teachers to condition student's brains in aligning and functioning of the right and left hemispheres of the brain, while the benefits for students to help align both hemispheres of their brain with material varied learning so that it can be stored for a long period of time.

Brain-based learning on speaking skills based on Eric Jensen's perspective which is divided into seven stages, namely [11]: 1) pre-exposure; 2) preparation; 3) initiation and acquisition; 4) elaboration; 5) incubation and coding memory; 6) verification and checking of belief; 7) celebrate and integration. Implementation of seven stages in brain-based learning by describing several brain hemispheres (beta, alpha, theta) accompanied by learning activities.

Table 1. Presentation of seven stages of brain-based learning

\begin{tabular}{|c|c|c|c|c|}
\hline No & Stages & $\begin{array}{c}\text { Brain } \\
\text { hemisphere }\end{array}$ & $\begin{array}{l}\text { Brain } \\
\text { waves }\end{array}$ & Activity \\
\hline 1 & Pre-exposure & Left brain & Alpha & Write or paste the title theme \\
\hline 2 & Preparation & Right brain & Alpha & $\begin{array}{l}\text { Describe or exchange information } \\
\text { about their experiences }\end{array}$ \\
\hline 3 & Initiation and acquisition & Left brain & Beta & Provide new information \\
\hline 4 & Elaboration & Left brain & Beta & $\begin{array}{l}\text { Present the theme in the form of } \\
\text { concept maps }\end{array}$ \\
\hline 5 & $\begin{array}{l}\text { Incubation and coding } \\
\text { memory }\end{array}$ & Right brain & Theta & Give free time \\
\hline 6 & $\begin{array}{l}\text { Verification and } \\
\text { checking of belief }\end{array}$ & $\begin{array}{l}\text { Left \& right } \\
\text { brain }\end{array}$ & Beta & Confirming ability \\
\hline 7 & Celebrate and integration & Right brain & Alpha & Give a simple game \\
\hline
\end{tabular}

Based on the table above, teachers implemented seven stages. They are: 1) pre-exposure, has a role to foster their interest in the theme to be discussing such as writing or pasting the title of the theme in whiteboard; 2) preparation, has a role to create curiosity or excitement in a learning [12], by revealing their experiences that contain new vocabulary according to theme; 
3) initiation and acquisition, have a role to provide concrete learning experiences such as case studies, experiments, interviews, and field trips[13], by receiving new information about new conversation texts and vocabulary; 4) elaboration, has a role to connect or explain the theme with real life in the form of concept maps; 5) memory incubation and coding, has a role to emphasize the importance of downtime and review time[14], by relaxing the mind and having students drink water, then close their eyes by listening to classical music; 6) verification and checking of trust, has a role to confirm the ability of students in understanding the material that has been studied; 7) celebration and integration, has a role to instill a love of learning with simple games. The explanation above can be concluded that the seven stages in brain-based learning can improve students speaking skills by knowing the condition of the students' brains by following brain waves. Alpha brain wave conditions are a meeting between the left and right brain, intellectual and imagination, conscious mind and subconscious [15]. The dominant beta condition is to actively think, concentrate, or focus on solving a problem [16]. Theta condition has a phase of increasing creativity, so students can find the right answers to complex and severe problems [17].

\subsection{The Factors Causing The Effectiveness}

The factors causing the effectiveness of brain-based learning on speaking skill based on Eric Jensen's perspective is adapted to field conditions. The researchers focused on the table to exposure the factors causing of effectiveness, below:

Table 2. Exposure the factors causing of effectiveness

\begin{tabular}{cll}
\hline No & \multicolumn{1}{c}{ Factors } & \multicolumn{1}{c}{ Activity } \\
\hline 1 & Coloring in learning & Application of various colors on learning media \\
2 & Deployment of concrete images & Application of real images on learning media \\
3 & Listening to music during the learning process & Application of classical music \\
4 & Give time for a drinking water & Give time to drink water \\
5 & Seating arrangements & Rotate a seat \\
\hline
\end{tabular}

Based on the explanation above, the researchers conduct analysis of factors causing the effectiveness of brain-based learning on speaking skills based on Eric Jensen's perspective with field conditions, they are: 1) the presence of coloring in learning process, according to Kurt can change the mood of students from sad to happy, from confusion to intelligence, from taste fear to be confident, so that the colors can flatten emotions and create different moods [18], the researcher applies a variety of colors to the learning media, that making students more leveling emotions and creating their different moods; 2) the application deployment of concrete images, because the brain can absorb all the information in visual form as much as 80 to $90 \%$, because the retina contributes about $40 \%$ of all and nerves connected with the brain [19], researchers apply real images to the media in accordance with the daily lives of students.

Furthermore, there are other factors that can support the effectiveness implementing brain based learning namely: 3) listening to music during learning process, according to Jalal the hypothesis of listening to music while learning languages, has activated both hemispheres simultaneously according to their respective functions, because music is processed by the right brain and language is processed by the left brain [20], researchers apply classical music when the hours are off and when learning takes place to support information to be brought to longterm memory; 4) give time for a drinking water, researchers give students time to drink water and move their bodies to increase oxygen in the body, so students do not feel bored, lethargy, drowsiness, and can not concentrate; 5) seating arrangements, according to Granstrom found 
that some students who sit in the back tend to interact more than those who sit in the front, which has the potential to adversely affect their attention to the learning to be faced [21], this factor can foster self-confidence, avoid boredom and reduce the incidence of neglect of the task.

\subsection{The Effectiveness Implementation of Brain-Based Learning}

In this study, the researchers wanted to know the effective implementation of brain-based learning on speaking skills based on Eric Jensen's perspective using the results pretest and posttest, by dividing the sample into two classes namely the control class and the experimental class. The test results using SPSS are as follows:

Table 3. Differences result pretest and posttest in control and experiment class

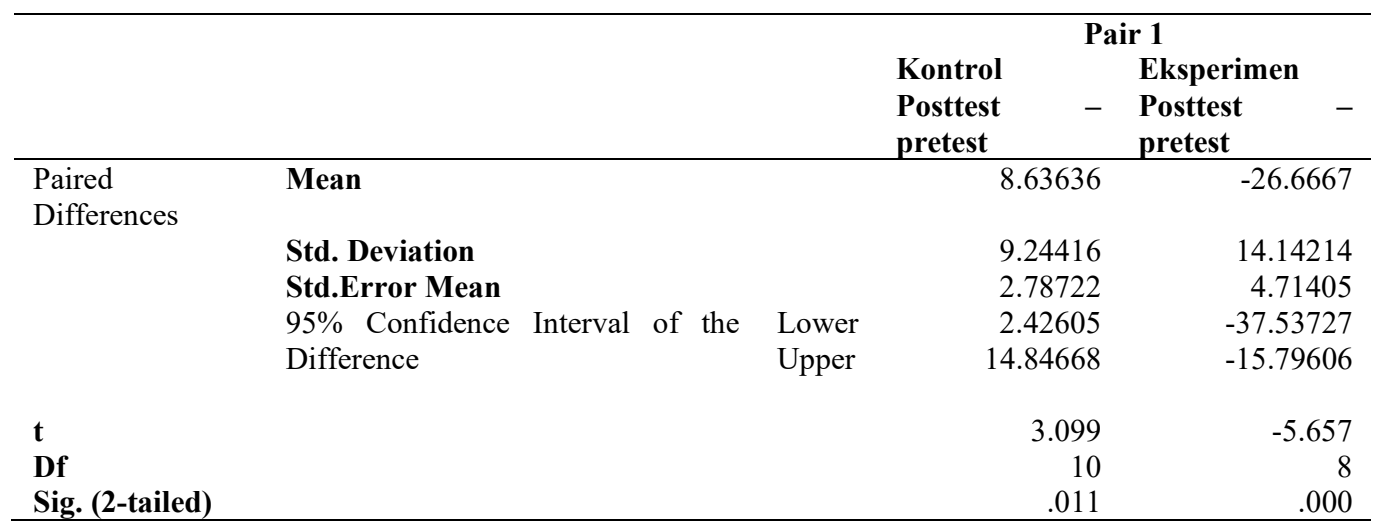

Based on the table above, there is a difference between the results of pretest and posttest of speaking skills in the control and experimental classes, that the value of the t-class of the control class is 3.099, while the t-table with calculations $(n-1=11-1=10)$ results are 2.282, and sig. ( 2 tailed) 0.011 which is smaller than $\alpha=0.05$. The value of $t$-count in the experimental class is 5.657, while the t-table with calculations $(n-1=9-1=8)$ results are 2.306, and sig. ( 2 tailed) 0,000 which is smaller than $\alpha=0.05$. With the difference in the results of the pretest and posttest in the control and experimental classes, it can be seen that brain-based learning is very effective to be applied in speaking skills [22]. Then the researchers concluded that there were differences in posttest results between the control and experimental classes after using brain-based learning on Eric Jensen's perspective.

\section{Conclusion}

It can be concluded that brain-based learning in MTs Nurul Huda Malang can be implemented to improve students speaking skills. This study can help teachers to develop a language environment can provide motivation and emotions of the students in developing brain that it has, when the brain students it needed a break and when the brain students that need motivation during the learning process. Then every teacher must change the way of their learning methods and thought in the cognitive, emotional, and motivational views that are by following two students' brain (right and left-brain) functions. 


\section{References}

[1] Oxford, Oxford Advanced Learner's Dictionary, 9th ed. Oxford University Press, 2018.

[2] S. Mustofa, Strategi Pembelajaran Bahasa Arab Inovatif. Malang: UIN Maliki Press, 2011.

[3] A. R. Fauzan, Idho'at Limuallimi Lughoh al-Arabiyah li-Ghairi Nathiqin Biha. Riyadh: Maktabah al-Mulk Fahdi Wathoniyah, 2011.

[4] Yi-Yuan Tang, Brain-Based Learning and Education: Principles and Practice. Academic Press Elsevier, 2017.

[5] M. G. Varghese, "Brain-based Learning- A compatible equation for stress management of students': An experimental study Abstract Abstract," no. Iv, pp. 871-876, 2013.

[6] V. Kartikaningtyas, T. A. Kusmayadi, and R. Riyadi, "Brain-based learning with contextual approach to mathematics achievement," Int. J. Sci. Appl. Sci. Conf. Ser., vol. 2, no. 1, p. 421, 2017.

[7] B. S. Handayani and A. D. Corebima, "Model brain-based learning (BBL) and whole brain teaching (WBT) in learning," Int. J. Sci. Appl. Sci. Conf. Ser., vol. 1, no. 2, p. 153, 2017.

[8] Ridvan Demir, "THE EFFECT OF RELIGIOUS CULTURE AND MORAL KNOWLEDGE COURSES BASED ON BRAIN- BASED LEARNING APPROACH ON ACADEMIC SUCCESS AND," vol. 5, no. 3, pp. 65-82, 2017.

[9] D. Hilmi, "Pengembangan Strategi Pembelajaran Keterampilan Berbicara Dalam Pendekatan Brain-Based Learning(Untuk Mahasiswa)," UIN Malang, 2013.

[10] Matthew B. Miles; A. Michel Huberman; Johnny Saldana, Qualitative Data Analysis A Methods Sourcebook Edition 3. United States of America, 2014.

[11] E. Jensen, Brain Based Learning Paradigm of Teaching. Jakarta Barat: PT. Indeks, 2011.

[12] U. P. Ganesha, "Pengaruh Model Pembelajaran TPS Berbasis Kearifan Lokal Terhadap Hasil Belajar IPS Siswa SD,” J. Ilmu Pendidik. Indonesia., vol. 002, pp. 1-10, 2013.

[13] M. Mekarina and Y. P. Ningsih, "The Effects of Brain-Based Learning Approach on Motivation and Students Achievement in Mathematics Learning," J. Phys. Conf. Ser., vol. 895, no. 1, 2017.

[14] M. G. Varghese and S. Pandya, "A Study on the Effectiveness of Brain-Based- Learning of Students of Secondary Level on Their Academic Achievement in Biology, Study Habits, and Stress," IASET Int. J. Humanit. Soc. Sci., vol. 5, no. 2, pp. 103-122, 2016.

[15] Anbowo, CODE. Jakarta: PT. Gramedia, 2009.

[16] E. Yulianto, A. Susanto, T. S. Widodo, and S. Wibowo, "Spektrum Frekuensi Sinyal EEG Terhadap Pergerakan Motorik dan Imajinasi Pergerakan Motorik,” Forum Tek., vol. 35, pp. 21 32, 2013.

[17] N. Yustisia, Hypnoteaching; Seni Ajar Mengeksplorasi Otak Peserta Didik. Yogyakarta: ArRuzz Media, 2012.

[18] S. Kurt and K. K. Osueke, "The Effects of Color on the Moods of College Students," SAGE Open, vol. 4, no. 1, p. $215824401452542,2014$.

[19] E. Jensen, Brain-Based Learning; Pembelajaran Berbasis Kemampuan Otak Cara Baru Dalam Pengajaran dan Pelatihan. Yogyakarta: Pustaka Pelajar, 2008.

[20] S. Jalal Abdolmanafi-Rokni and A. Jannati Ataee, "The Effect of Background Music on Vocabulary Recall and Retention of Children Learning English as A Foreign Language," Int. J. Basic Sci. Appl. Res., vol. 3, no. 8, pp. 491-495, 2011.

[21] M. M. Haghighi and M. M. Jusan, "Exploring Students Behavior on Seating Arrangements in Learning Environment: A Review," Procedia - Soc. Behav. Sci., vol. 36, no. June 2011, pp. 287 294, 2012.

[22] A. Darmuki, Andayani, J. Nurkamto, K. Saddhono, "The Development and Evaluation of Speaking Learning Model by Cooperative Approach,” Int. J. of Ins., vol. 11 no. 2 pp. 115-128, 2018 